\title{
Gravity of the non-authorized use of substances not intended for clinical use in invasive aesthetic procedures: the portuguese case
}

\author{
(D) Nuno Correia Louro Fradinho 1, 2,3,4,5,6 \\ (iD) Pedro Miguel Alves Ribeiro Correia $\mathbf{7 , 8 , 9 , 1 0 , 1 1 , 1 2 , 1 3}$ \\ 1. Advanced Health Management Program, Catolica Lisbon Business School, Portuguese Catholic University (UCP), Lisbon, Portugal \\ 2. Licentiate's Degree in Medicine by the Institute of Biomedical Sciences Abel Salazar, University of Porto (ICBAS-UP), Porto, Portugal \\ 3. Hospital Assistant in Reconstructive and Aesthetic Plastic Surgery, Hospital Center of Central Lisbon (CHLC), EPE, Lisbon, Portugal \\ 4. Advisor to the Direction of the Medical Internship, Hospital Center of Central Lisbon (CHLC), EPE, Lisbon, Portugal \\ 5. Direction of the Portuguese Society of Reconstructive and Aesthetic Plastic Surgery (SPCPRE), Lisbon, Portugal \\ 6. Regional Southern Council of the Doctors Order, Lisbon, Portugal \\ 7. Doctorate in Social Sciences (specialized in Public Administration), Technical University of Lisbon (UTL), Lisbon, Portugal \\ 8. Licentiate's Degree in Statistics of Information Management, New University of Lisbon (NOVA), Lisbon, Portugal \\ 9. Vice President and Integrated Researcher at the Centre for Public Administration and Public Policies (CAPP), ISCSP-ULisboa, Lisbon, Portugal \\ 10. Collaborating Researcher of the Interdisciplinary Center for Gender Studies (CIEG), ISCSP-ULisboa, Lisbon, Portugal \\ 11. Foreign collaborator of the Research Group in the Administration of Justice, University of Brasília, Brasília, DF, Brasil \\ 12. Consultant to the Planning and Legislative Policy Department of the Directorate General for Justice Policy (DGPJ) \\ of the Ministry of Justice of Portugal, Lisbon, Portugal \\ 13. Study conducted in Lisbon, Portugal
}

http://dx.doi.org/10.1590/1806-9282.65.3.410

\begin{abstract}
SUMMARY
INTRODUCTION: There is a worldwide increase in the number of invasive aesthetic procedures, and there is a general apprehension in medical societies towards the assurance of patient safety, that is dependent on the quality and certification of providers, of the materials and substances used, and where they take place.

It is the main objective of this study to determine the perception of the gravity of non-authorized substances for clinical use in invasive aesthetic procedures among Portuguese plastic surgeons and its variation by the clinical sector of practice.

METHODS: We proceeded to an inquiry by using a questionnaire, measured in a Linkert scale, and the collected data were statistically treated with a non-parametric Kruskal-Wallis test.

RESULTS: We obtained a 41,4\% answer rate and a global perception that this is a serious problem - a median of 8,00 and mean of 7,45 points on a 1 to 10 scale. $70 \%$ of the plastic surgeons that answered the questionnaire work both in the private and public sector, $19 \%$ exclusively in the public sector and $11 \%$ only in private practice. The perception of the problem was most serious among those that work exclusively in the private sector (statistically significant difference).

CONCLUSION: The causes of the observed difference may reside in various reasons: the higher number of patients submitted to invasive aesthetic procedures exclusively in private practice; the higher perception of regulatory deficits in the private sector; scarce specific health politics for procedures outside the traditional boundaries of medicine; the difficulty for independent regulatory agencies to adopt effective measures.

KEYWORDS: government regulation; medical device legislation; esthetics; certification; plastic surgery.
\end{abstract}

DATE OF SUBMISSION: 15-Aug-2018

DATE OF ACCEPTANCE: 02-Oct-2018

CORRESPONDING AUTHOR: Pedro Miguel Alves Ribeiro Correia

Instituto Superior de Ciências Sociais e Políticas, Rua Almerindo Lessa, 1300-663 Lisboa, Portugal

1300-663 - Tel:[+351] 213619430 - Fax: [+351] 213619442

Email: pcorreia@iscsp.ulisboa.pt 


\section{INTRODUCTION}

All around the world, worrisome reports of invasive procedures performed outside of health institutions - in business centers, hair salons, beauty salons, private houses, social gatherings, parties, etc. - have been surfacing. The risks of invasive procedures outside the clinical context are multiple: inadequate selection of patients, peer pressure to consent to treatment, professionals who are not qualified to perform the procedures or unable to control/treat possible complications, ineffective quality control, storage and dosage of substances administered, weak follow-up of patients in the period after the treatment, the possibility of alcohol and other substances being mixed with analgesic medication, among others ${ }^{1}$.

To our knowledge, there are no published studies on the regulation of invasive aesthetic procedures in Portugal, on the number of treatments that are performed outside the clinical context, or about the impact they have on the health of patients. The real dimension of the problem of aesthetic procedures performed outside the clinical context and its direct impact on the health of patients is very difficult to determine with accuracy, since they are not, in their majority, reported to authorities or to the medical and scientific communities. You can infer, however, the seriousness of the matter through the perception of professionals who legally carry out these procedures and treat the complications derived from bad practices by others, and the regulatory mechanisms in relation to this specific issue.

\section{METHODS}

We used a survey by questionnaire as the empirical instrument of data collection for this study. The total universe of plastic surgeons who are active members of the Portuguese Society of Reconstructive and Aesthetic Plastic Surgery that were surveyed (128), resulted in 53 responses considered valid for the characterizing variable of "area of exercise of the professional activity," determining a response rate of $41.4 \%$. For the characterization of this variable, we used the following categories: "public sector alone"; "private sector alone"; "public and private sectors."

The latent variable used was the perception that the use of devices or substances not authorized for clinical use, in aesthetic procedures, is a serious problem; this was measured using the Likert rat- ing scale with 10 points, limited at the extremities - lower extremity: "completely disagree"; upper extremity: "agree completely."

The absence of normality in the distribution of levels obtained for the latent variable did not allow for the use of the Shapiro-Wilk test to determine the statistical relationships existing in the sample data. Therefore, it was necessary to use the Kruskal-Wallis non-parametric test ${ }^{2,3}$ which allowed for the statistical analysis of the data. The statistical tests used $0.05(5.00 \%)$ as a reference significance level.

\section{RESULTS}

Of the 53 observations, the majority (70\%) corresponds to mixed work regimen (accumulation of functions), 19\% are from the public sector exclusively and $11 \%$ from the private sector exclusively (Table 1).

The average of total value is 7.45 and the median, 8.00 in a Likert scale (1 to 10$)$, reflecting a widespread perception that the problem of unauthorized substances for clinical use in aesthetic procedures is a serious one. The values obtained for the medians (and averages) of the seriousness of the problem, per sector of activity, are presented in Chart 1 . This perception of the severity stands out on private sector category, with a median of 10.00 points (average of 9.33), i.e., 2.00 points above the value of the total median (1.88 point above the global average), while the categories that involve the public sector have lower scores - a median of 8.50 points (1.88 point above the global median) an average of 8.20 points (0.75 point above the global average) in the category of public sector alone; and median of 7.00 points (1.00 point below the global median) and an average of 6.95 points (0.50 point below the global average) in the mixed category with roles in the public and private sectors.

TABLE 1. NUMBER OF OBSERVATIONS PER SECTOR OF ACTIVITY AND ITS PERCENTAGE WEIGHT

\begin{tabular}{l|l|l}
$\begin{array}{l}\text { Your clinical practice belongs } \\
\text { to which sector of activity? }\end{array}$ & $\begin{array}{l}\text { Number of } \\
\text { observations }\end{array}$ & $\begin{array}{l}\text { Percentage of } \\
\text { total }\end{array}$ \\
\hline Private sector alone & 6 & 11.3 \\
\hline Public sector alone & 10 & 18.9 \\
\hline Private and public sectors & 37 & 69.8 \\
\hline Total & 53 & 100 \\
\hline
\end{tabular}


CHART 1. PERCEPTION VALUES OF THE GRAVITY OF THE USE OF SUBSTANCES NOT AUTHORIZED FOR CLINICAL USE IN AESTHETIC PROCEDURES PER SECTOR OF ACTIVITY

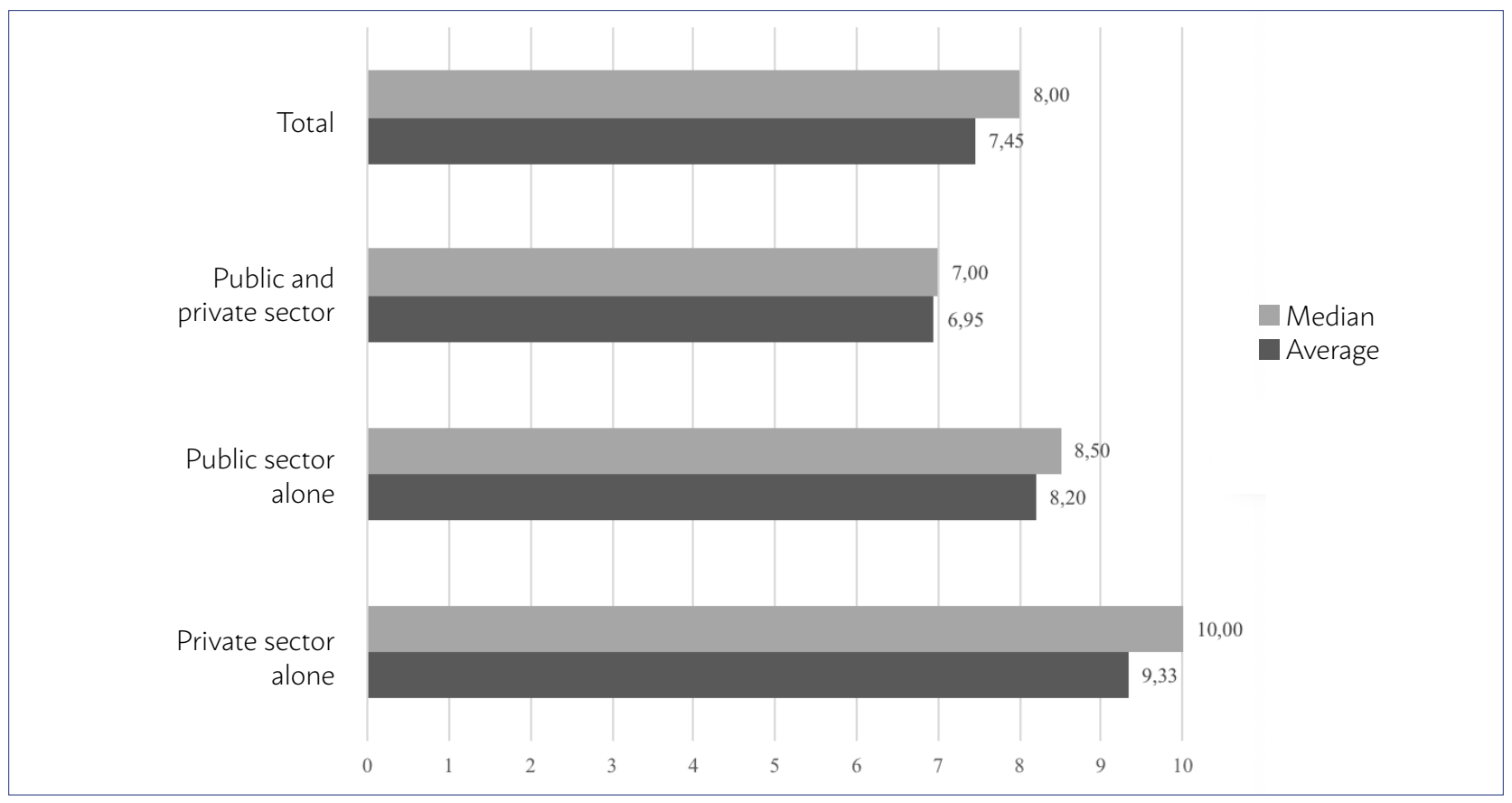

TABLE 2. SHAPIRO-WILK TEST APPLIED TO THE MEDIANS OF THE SCORES OF EACH SECTOR OF ACTIVITY (P-VALUE 0.05)

\begin{tabular}{l|l|l|l|l|} 
Your clinical practice belongs to which sector of activity? & \multicolumn{3}{l}{ Shapiro-Wilk } \\
\cline { 3 - 6 } \begin{tabular}{l} 
Statistics \\
\cline { 3 - 5 }
\end{tabular} & df & Sig. & \\
\hline I believe that, in Portugal, the & Private sector alone & 0.640 & 6 & 0.001 \\
\cline { 2 - 6 } $\begin{array}{l}\text { use of devices or substances } \\
\text { not authorized for clinical use } \\
\text { in aesthetic procedures is a } \\
\text { serious problem. }\end{array}$ & Public sector alone & 0.832 & 10 & 0.035 \\
\cline { 2 - 6 } & Private and public sectors & 0.898 & 37 & 0.003 \\
\hline
\end{tabular}

TABLE 3. KRUSKAL-WALLIS TEST, WITH VARIABLE GROUPED PER "SECTOR OF ACTIVITY"

\begin{tabular}{l|l} 
& $\begin{array}{l}\text { I believe that, in Portugal, the use of } \\
\text { devices or substances not authorized } \\
\text { for clinical use in aesthetic proce- } \\
\text { dures is a serious problem. }\end{array}$ \\
\hline Chi-Square & 6.112 \\
\hline df & 2 \\
\hline Asymp. Sig. & 0.047 \\
\hline
\end{tabular}

It is necessary to determine whether these differences are statistically significant or may be due to random fluctuations in the data. Once it was determined that the distribution of scores was not normal using the Shapiro-Wilk test (p-value < 0.05), as described in Table 2, it was necessary to use the Kruskal-Wallis non-parametric test.

Examples of the use of this test can be found in other articles published in the scientific literature ${ }^{3-6}$.

In Table 3 we can see that the p-value of $0.047 \mathrm{ob}$ tained from this test is below the level of significance (0.05).

From the results obtained by the comparison between the results of the Kruskal-Wallis test, through the stepwise method applied to the middle ranking of each sector of activity, it is possible to assume the existence of two subgroups of plastic surgeons: one that works exclusively in the private sector (with a higher value for the severity perception of the use of unauthorized substances in aesthetic procedures), and another which encompasses the public sector exclusively and the combination of public and private sectors (with lower perception values).

These facts lead to rejection of the null hypothesis of the test and the acceptance of the alternative hypothesis, which attests to the existence of statistically significant differences in the median of the perception of plastic surgeons on the seriousness of the use of substances not authorized for clinical use in invasive aesthetic procedures varying according to the sector of activity. Therefore, this perception is not uniform, and the relationship between it and the sector of activity is statistically confirmed by these data: the medians of scores of the private sector alone are higher than those that involve the public sector.

\section{DISCUSSION}

Iatrogenic lesions in plastic surgery caused by substances not suitable for clinical use are well 
known, and there are cases described in which industrial silicone, liquid paraffin, soy oil, among others were used ${ }^{7}$. After the Second World War, this type of experimentation was frequent ${ }^{8}$, but progressively its use was restricted and regulated. In recent years, there has been a growing number of aesthetic procedures at a global level: in 2015 more than 21 million surgical and non-surgical procedures were performed (an increase of 1 million since 2014); the application of botulinum toxin (the most frequently used) and the infiltration of hyaluronic acid had an increase of $4 \%$ and $7 \%$ compared to the previous year, respectively ${ }^{9}$. This boom in demand for aesthetic procedures seems to be followed by a growth in irregular situations. The widespread perception among the plastic surgeons who responded to the survey is that the use of substances or devices not approved for clinical use in aesthetic procedures is a serious problem, with a median of 8 points (average of 7.45) on a scale of 1 to 10 . However, there is a statistically significant difference between the perception of plastic surgeons who work exclusively in the private sector and those who work in the public sector (exclusively or in a combination of roles). This difference may be due to:

- a greater number of patients who undergo this type of procedures conducted by plastic surgeons who devote their entire activity to the private sector, since these patients attend, almost exclusively, private institutions (except for major complications that require hospitalization). Consequently, they see a higher number of complications caused by the use of unauthorized substances used by others, which causes greater apprehension.

The work in private institutions alone has a different administrative paradigm from that of the public sector, which is more exposed to possible failures in the regulatory mechanisms of the professional activity and of the substances administered.

According to a survey conducted by the SPCPRE with its members and presented at the III Iberian Congress of Plastic Surgery (2016), half of the plastic surgeons recently observed patients that underwent implantation of devices or substances not authorized for clinical use ${ }^{10}$. This observation reflects a worrying reality for citizens' health and may be related to several factors. There are procedures that are not performed by qualified professionals, which can facilitate circumvention of the regulatory mechanisms and stimulate the unscrupulous use of appropriate substances; patients may not be adequately informed about the type of procedures, the substances used, and the qualifications of those who will practice invasive aesthetic procedures ${ }^{11}$; and the regulatory mechanisms may not be keeping up with this phenomenon, having difficulties with the effectiveness of their actions, because of:

The complexity inherent to certain specific issues, and in particular aesthetics, which are common to other countries, irrespective of their political and administrative reality.

The existence of different ethical foundations of Anglo-Saxon and European countries, with practical implications determinants of different administrative processes and organizational models - the Anglo-Saxon management and pragmatics, based on the implementation of effective, preventive, and formative mechanisms, in opposition to the European legalistic and conceptual model, with is repairing and far from the "practice"12.

Cultural differences - beliefs and values of public administration, which are in conflict with this increasingly mixed model.

The relative lack of experience in this type of independence of regulatory agencies under the unifying State. There are similarities between the public and private administration in the Anglo-Saxon model, and the administrative process is seen as a means for achieving goals, with obvious gains in effectiveness and efficiency (instrumentalist); this model contrasts with the Continental European model, which sees the public and private administration as completely different spheres, with their own instruments - restraining even the public administration in a separate code of rules and legislative system, with few points of contact with the general law. Comparatively, the Anglo-Saxon approach there are similarities in the administrative functions of the public and private sector, differing mainly on strategic issues, while in the Continental European approach the similarities are avoided and the public administration is based on principles necessarily different from those adopted in private administration, very dependent on legal/ normative regulations ${ }^{12}$.

Aesthetic procedures introduce bodily changes with the aim of improving physical appearance and, consequently, increasing self-esteem. Some are not considered healthcare in Portugal (manicure, mechanical epilation, tattoos, for example) and are 
performed in beauty and hair salons, for example, without the need for regulation of the provider. In the United Kingdom, on the other hand, the majority of these activities is seen as "health" activities and are regulated by the Ministry of Health. The already historically fluid boundaries between hygiene, medicine, and beauty are undefined when it comes to aesthetics.

The role of the State is also different in how it sees plastic surgery, depending on the type of procedure. Reconstructive plastic surgery procedures, as are included in the list of procedures offered by the National Health Service (SNS), inhabit the Continental European administrative paradigm with a strong presence of the State as provider, funder, and regulator and with a normative influence inherited from the French influence of the 18th and 19th centuries by Bonnin ${ }^{13}$, based mainly on administrative law. Plastic surgery procedures, in its aesthetic aspect, are inserted in an open market, of private services and free competition, and fall more into the Anglo-Saxon paradigm typical of private providers of health care, in which the State retains only the role of regulator. This role of attentive spectator-intervener, in an open but regulated market, has long historical practice in common law countries, with a tradition and well-established mechanisms that have been refined over time ${ }^{14}$. In Portugal, there has been a gradual importation of management measures in public administration since the years 1980-1990 New Public Management - with a greater increment in the period of financial rescues in the 1980s (mainly by the influence of the International Monetary Fund) and, more recently, in the troika intervention. Despite political and historical-institutional differenc$\mathrm{es}^{15}$, as part of this package of measures independent regulatory institutions were created in various sectors. The need to regulate a market arises when one of the following assumptions is present: monopolies, externalities, asymmetric information, the need for continuity of service, anticompetitive behavior, the existence of a public good, when the bargaining power is unequal, if there is a shortage of resources and/ or need of rationing, or due to a need for planning ${ }^{16}$. The public good identified, in the case of aesthetic procedures, is not only the direct result of the actions (improvement of the physical appearance or delay of the effects of aging) but the preservation of the security of these actions, i.e., mitigating or minimizing the health risk of these procedures. We can infer, then, that health or, more specifically, the maintenance of the health state in aesthetic procedures is also regarded as a public good.

The Law framework of independent administrative entities with regulation functions stipulates that "the regulation entities are collective persons of public law, with the nature of independent administrative entities with attributions in the field of regulation of economic activity, protection of services of general interest, protection of the rights and interests of consumers, and promotion defense of competition in private, public, social and cooperative sectors" ${ }^{\prime 17}$. In this way, the transition from the separation of State and market economy establishes a social value to the public regulation ensuring equality of opportunity for competition and guarantying the obligations of public service of the various sectors of society. There is, therefore, an understanding of regulation as a new form of relationship between the State and society, creating additional social value, by means of norms that ensure the balanced functioning of the open system (market) in agreement with public objectives.

The tendency for the formation of independent administrative authorities have in common at least three characteristics: the recognition that regulation has a specific logic and should, whenever possible, be separated from the political logic; the recognition that the market has flaws and not always gives guarantees of finding the balance of the system for the fulfillment of their public obligations; the recognition that the State is also flawed due to its administrative burden, its causal guidelines, corporatism, among others, which restrict the public interest ${ }^{18}$.

In the health sector, these management modifications are mirrored in the plan of Reduction and Improvement of the Central Administration (Premac), considered by the tutelage as "[...] the beginning of a new phase of the reform of Public Administration, in order to make rational and efficient use of public resources. [...] Indeed, more than ever, the simultaneous achievement of the objectives of rationalization of state structures and better use of human resources is crucial in the process of modernization and optimization of the functioning of Public Administration". ${ }^{19}$ This focus on the pursuit of efficiency and rationalization of resources was subsequently achieved by the creation of new independent administrative bodies with powers of supervision and regulation, such as the General Inspection of Health 
Activities (Igas), or the independence of already existent autonomous structures, such as the Health Regulatory Body (ERS). This was created in 2005, in the process of autonomizing the regulatory agencies - which was already a management measure part of the New Public Management.

From the normative point of view, until recently the blurring of what is a health and a medical procedure persisted. We found that the Portuguese legal system does not include a isolated definition of the medical procedure, but there is a reservation of exercise on procedures of medical diagnosis, therapeutic prescription, and autonomous management of patients ${ }^{20}$. In addition to the difficulty in clarifying exactly what is and what is not a medical procedure, or a procedure restricted to health professionals, there is a normative vacuum in the classification of what is an invasive procedure". If one considers, on the one hand, that a tattoo, a body piercing, laser/pulsed light hair removal are invasive because they penetrate completely or partially the protective barrier of the skin, and because they can cause serious damage, temporary or permanent (transmission of diseases, hemorrhages, skin burns, eye injuries, among others), in practice, they are often used by people without any basic health training, performed solely based on "common sense". The project for a legal definition of Health Procedure is restricted to eight professions, trying to refer to a specific procedure of each professional activity, but described in very general terms ${ }^{21}$.
Within these professions, it is understood from the remaining national regulatory framework that "acts of medical diagnosis (unlike the nursing diagnosis), prescribing treatment (unlike the non-therapeutic prescription) and autonomous management of patients constitute acts of absolute exclusivity of the medical profession. [...] The other acts, functionally considered as acts of the medical profession, appear to be susceptible to being delegable to other health professionals, including nurses, upon authorization of the Order of Doctors and within limits defined by a initial medical prescription"20.

The legislation itself that defines the competencies of each entity with the power to regulate in the area of health has an overlapping of competences and their limits of action, which can induce the existence of "gray areas" that are the legal responsibility of several entities, but which, in practice, are not supervised by none. Perhaps to overcome some of these shortcomings, a protocol of cooperation between the ERS and the professional orders of the health sector was recently signed to "cooperate in the sharing of resources, both human and technical, and of knowledge with the purpose of improving the exercise of their respective attributions" and provides for the participation of professional orders in the planning and execution of supervisory actions, surveys, monitoring, and periodic evaluations"22.

The Botulinum Toxin, for example, authorized by Infarmed for administration by "physicians ex-

TABLE 4. ENTITIES WITH RESPONSIBILITY IN THE REGULATION IN THE HEALTH AREA AND THEIR POWERS

\begin{tabular}{|c|c|}
\hline $\begin{array}{l}\text { Health Regulatory } \\
\text { Entity }\end{array}$ & $\begin{array}{l}\text { Regulates and inspects only the institutions registered as providers of health care - clinics, private clinics, hospitals } \\
- \text { and has no powers of supervision of certification of the provider and of the quality of most substances and devices } \\
\text { used in aesthetic procedures. However, it is stipulated that its influence extends to "any other places where it is materi- } \\
\text { ally identified the practice of activities that integrate the concept of health care provision, as defined by the ERS" }\end{array}$ \\
\hline $\begin{array}{l}\text { General supervision } \\
\text { of health activities }\end{array}$ & $\begin{array}{l}\text { Its mission is to audit, inspect, supervise and develop disciplinary action in the health sector in order to ensure com- } \\
\text { pliance with the law and high technical levels of performance in all areas of activity and the provision of health care } \\
\text { through services, establishments and bodies of the Ministry of Health [...], or protected by it, either by private entities, } \\
\text { collective persons, profit or non-profit". This agency has the power to "supervise the compliance with legal provisions } \\
\text { and regulations and the applicable guidelines, as well as the quality of services rendered by any entity or professional } \\
\text { in the field of health activities, through the implementation of actions of audit, i, spection and supervision"; and to } \\
\text { carry out regular services of inspection at the level of safety and quality, in conjunction with the General Directorate of } \\
\text { Health (DGS)"19. }\end{array}$ \\
\hline Infarmed & $\begin{array}{l}\text { Has the mission to "contribute to the formulation of national health policies", "regulate, evaluate, authorize, punish, } \\
\text { supervise, check analytically, and ensure the monitoring and control of research, production, distribution, marketing } \\
\text { and use of medicinal products for human use and health products, which includes medical devices and cosmetics and } \\
\text { personal hygiene products," as well as "ensure the regulation and supervision of the activities of research, production, } \\
\text { distribution, marketing and use" of these products and devices }{ }^{36} \text {. }\end{array}$ \\
\hline Order of Doctors & $\begin{array}{l}\text { Has the powers to regulate the access and the exercise of the profession of physician and exercise disciplinary power } \\
\text { over them: its code of ethics provides disciplinary sto doctors doctors who go beyond the limits of their powers, taking } \\
\text { into account the specialties and subspecialties - usually after complaint }{ }^{37} \text {. Should collaborate with other entities of } \\
\text { the Public Administration in matters of public interest related to the medical profession and contribute to the protec- } \\
\text { tion of the health of citizens and the rights of patients, as well as participate in the drafting of legislation which relates } \\
\text { to the access to and pursuit of the medical profession }{ }^{38} \text {. }\end{array}$ \\
\hline
\end{tabular}


perienced in the application of botulinum toxin" (informative leaflet), is sold only with a prescription. However, this type of medication in pharmacies is easily obtained for application by non-doctors, and there is not a mandatory registration of the prescriber per package. In Spain, for example, the government has made some progress in regulating this type of procedures through the control of the circuit of the active substances and the certification of the provider. The Botulinum Toxin used with aesthetic indication has the same regulation of medicines for hospital use and can only be administered by "physicians with the proper qualification, experience in the treatment, and with the appropriate equipment and instrumentation. As a result, and to ensure that the proper administration of these treatments can only be performed in hospitals or health care institutions that are duly authorized in accordance with the legislation in force"23. The transport, storage, and recording of packages follow the same requirements of medicines for hospital use only. There is also a requirement that the doctor fills out a standard sheet with the reference of the packaging, the date, and the dose of administration, for reporting to the health authority, as well as an informational letter for patients who will receive the medication for the first time, containing the goals of the treatment, an explanation of the procedure and the risks involved.

Subcutaneous fillers to gain volume are also considered medical devices for exclusive medical use, but there is little control of their use. There are also reported cases of fraud and counterfeiting of facial filler products based on hyaluronic acid ${ }^{24}$. With globalization and the expansion of the digital commerce, nowadays it is easier to bypass regulating agencies and order substances and devices, over the internet, that are released for "clinical use" and "without control by national and international medication agencies."

However, this problem is not confined to the national reality; it is an international phenomenon. Rufai and Davis believe that cosmetic surgery in the United Kingdom is also "ubiquitous, unregulated, and seductive," there is no great adherence to national guidelines ${ }^{25}$. The lack of control over the qualification of suppliers may be a predisposing factor to the use of substances not authorized for clinical use. Then, the question that arises is: who has the qualifications to provide this type of care?26 The use of training programs, the regulation of sectors, profes- sional certification and the constant and systematic evaluation along the professional career are contemporary manifestations of the logic of scientific management. The desire of societies for certification, accuracy, organization and appropriate categorization of the world to find a sense in it is, without a doubt, as strong today as it was at the foundation of scientific management ${ }^{27}$, and is compatible with the need for control and security of citizens themselves.

In the USA, the most important factor for patients in choosing a provider of aesthetic procedures is the certification in plastic surgery ${ }^{28,29}$, and the greatest fear is to obtain "bad results" ${ }^{30}$. Even so, many of the providers of aesthetic procedures in the country are not certified by the American Society of Plastic Surgeons (ASPS) ${ }^{31}$ or by other medical societies. A growing phenomenon is also the emergence of inaccurate qualifications that do not correspond to any type of degree or certification - "aesthetic surgeon", "aesthetic doctor", "facial plastic surgeon", "cosmetic surgeon", as a way to disguise the absence of a certification recognized by the national medical associations. Usually, the provider with this type of (self) qualification is a general medical practitioner or has another specialization less "seductive" for aesthetic procedures, or is a non-medical healthcare professional, or even someone without any qualification in health care provision. This type of marketing maneuver is frequent and is also observed abroad, with several calls for government intervention. ${ }^{26,32}$.

In Portugal, the regulation of advertising of health procedures has recently been legislated as an attribution of the ERS and, in this context, it is deemed to be unlawful if it induces the patient to procedures that are unnecessary, harmful or without prior diagnosis or evaluation by a "qualified professional"; and "every time the professional favored by the practice of health advertising is also the health care provider, without actually being one, or if they are a health care provider but do not comply with the requirements of activity and operation, are not duly registered with the regulatory body of health and do not hold a license of operation, when applicable"..$^{33}$

Recently, there has been a controversial attempt to regulate the activity of beauty salons by the European Committee for Standardization (CEN). About two years ago, the organization gathered a group of experts for the development of the CEN-409 normative for beauty salons ${ }^{34}$. This project was withdrawn in 2016 due to numerous complaints from local com- 
mittees and national entities related to health, due to the possible ethical commitment to the safety of patients if the law were approved. On the basis of these allegations was the type of procedures that could be performed in "beauty salons" or equivalent, such as laser treatments, IPL, mesotherapy, ultrasounds, radiofrequency, chemical peels, without restrictive criteria of power, penetration, and depth, for example. According to the entities that complained about the normative proposal, these invasive aesthetic procedures should be performed by physicians or under the supervision of one, based on a clinical diagnosis, and in institutions properly regulated and supervised.

In practice, there seems to be a lack of supervision of economic activities not registered as health establishments based on clinical criteria - including "aesthetic centers", hair salons and beauty salons. There seems to be only, in practice, control of the activity in terms of quality of infrastructures, security, and tax transparency by means of the Economic and Food Safety Authority (ASAE).

\section{CONCLUSION}

Although the entities with the power to regulate the health sector have responsibilities defined by law to act on the various market segments of aesthetics
- with an overlapping of functions - and have the duty to cooperate among themselves, there is a widespread perception among plastic surgeons who are accredited providers that the use of substances not authorized for clinical use in invasive aesthetic procedures is a serious problem. This perception is more pronounced in surgeons who exercise their activity exclusively in the private sector.

The regulation of the various segments that constitute the circuit of these substances - production, marketing, distribution, utilization, monitoring, inspection, evaluation - by agencies that are still incorporating instruments of independent or autonomous action, imported from countries with different administrative histories and cultures (management), may not prove to be effective in a real level, with the aggravating circumstance that this market also finds difficulties of effective regulation at an international level. The fact that this is a recent problem at a global scale has not yet allowed for the creation of specific health policies and effective administrative solutions.

Greater supervision and transparency are necessary in order to increase the safety of patients and the reliability of results ${ }^{26}$.

\section{Acknowledgments}

Portuguese Society of Reconstructive and Aesthetic Plastic Surgery

\section{RESUMO}

INTRODUÇÃO: Os procedimentos estéticos invasivos estão a aumentar globalmente, e são acompanhados por uma apreensão das sociedades médicas sobre a segurança desses procedimentos, dependentes da qualidade e certificação dos prestadores, dos dispositivos e substâncias utilizados e do local onde são efetuados. O presente estudo procura aferir a percepção dos cirurgiões plásticos portugueses sobre a gravidade da utilização de substâncias não autorizadas para uso clínico em procedimentos estéticos, e a sua variação consoante o setor em que exercem a atividade clínica.

MÉTODOS: Foi utilizado um inquérito sob a forma de questionário, medido numa escala de Likert, e os dados foram tratados estatisticamente pelo teste não paramétrico de Kruskal-Wallis.

RESULTADOS: Obteve-se uma taxa de resposta de 41,4\% e a perceção global é a de que o problema é grave - mediana de 8,00 e média de 7,45 numa escala de 1 a 10. Setenta por cento dos cirurgiões plásticos que responderam ao inquérito trabalham num regime misto, $19 \%$ exclusivamente no setor público e $11 \%$ apenas no setor privado. A percepção do problema como mais grave (diferença estatisticamente significativa) foi observada na atividade exclusiva no setor privado.

CONCLUSÕES: A diferença observada pode dever-se a vários fatores: à maior observação de pacientes submetidos a esses procedimentos exclusivamente no setor privado; à maior percepção de déficits de regulação no setor privado; ao déficit de políticas de saúde específicas a técnicas utilizadas fora do contexto tradicional da medicina; à dificuldade de as agências administrativas reguladoras independentes adotarem práticas efetivas no setor privado da saúde.

PALAVRAS-CHAVE: Regulamentação governamental. Legislação de dispositivos médicos. Estética. Certificação. Cirurgia plástica. 


\section{REFERENCES}

1. ASPS, ASAPS. Injectables and Fillers: Legal and Regulatory Risk Management Issues. Plast Reconstr Surg. 2006;118(Suppl):129S-132S. doi:10.1097/01.prs.0000214727.21086.0c

2. Kruskal WH, Wallis WA. Use of Ranks in One-Criterion Variance Analysis. J Am Stat Assoc. 1952;47(260):583. doi:10.2307/2280779.

3. Correia P, Carrapato P, Bilhim J. Administração hospitalar em Portugal: relação entre antiguidade e envolvimento laboral, e implicações para o risco de saída. / Bras Econ da Saúde. 2016;8(2):73-79. doi:10.21115/JBES.v8.n2. p73-79.

4. Catarino |, Correia P. Receitas fiscais e tributação geral sobre o consumo em Portugal : um estudo sobre eventuais assimetrias do comportamento dos sujeitos passivos do imposto no final da primeira década do século XX [Tax Revenue and General Taxation on Consumption in Portuga. Rev da FAE. 2016;19(1):6-17.

5. Correia P, Catarino J. Ingreso Bruto Tributable del IVA: Evidencia de Diferenciación de los Municipios de la Costa Portuguesa [Gross Revenue for VAT Tax: Evidence of Differentiation at the Portuguese Littoral Municipalities]. Rev del CLAD Reforma y Democr. 2016;64:225-246.

6. Correia P, Videira SA. Troika's Portuguese Ministry of Justice Experiment, Part II: Continued positive results for civil enforcement actions in Troika's aftermath. Int / Court Adm. 2016;8(1):20. doi:10.18352/ijca.215.

7. Grotting IC, Neligan PC. Plastic Surgery: Volume 5: Breast. Elsevier Health Sciences; 2012. https://books.google.pt/books?id=DT7)hnV1_B4C.

8. Goulian D. Current status of liquid injectable silicone. Aesthetic Plast Surg. 1978;2(1):247-250. doi:10.1007/BF01577957.

9. International Society of Aesthetic Plastic Surgery. ISAPS International Survey on Aesthetic/Cosmetic Procedures Performed in 2015.; 2016. https:// www.isaps.org/Media/Default/global-statistics/2016 ISAPS Results.pdf.

10. Sociedade Portuguesa de Cirurgia Plástica Reconstrutiva e Estética, Sociedad Española de Cirurgía Plastica Reparadora y Estetica. Segurança e Saúde Pública em Cirurgia Plástica. 2016. cprelisboa.org.

11. Manstein C. Preferences regarding board certification and organization relating to aesthetic surgery. Plast Reconstr Surg. 1998;(110):863-864.

12. Bilhim J, Ramos R, Pereira LM. Paradigmas administrativos, ética e intervenção do Estado na economia: o caso de Portugal. Rev Digit Derecho Adm. 2015;0(14):91. doi:10.18601/21452946.n14.07.

13. Bonnin C). Les Principes D'administration Publique. 3rd ed. Paris: Renaudiere, Imprimeur-libraire; 1812.

14. Bilhim J. Ciência Da Administração. Lisboa: Instituto Superior de Ciências Sociais e Políticas; 2013.

15. Moreira V. Autoridades Reguladores E Independentes - Estudo E Projeto de Lei-Quadro. Coimbra: Coimbra Editora; 2003.

16. Day P, Klein R, Redmayne S. Why Regulate?: Regulating Residential Care for Elderly People. Bristol: The Policy Press; 1996.

17. Assembleia da República. Lei N. ${ }^{\circ} 67 / 2013$ de 28 de Agosto: Lei-Quadro Das Entidades Administrativas Independentes Com Funções de Regulação Da Atividade Económica Dos Setores Privado, Público E Cooperativo. Portugal: Diário da República; 2015:7566-7584.

18. Pereira PT. Governabilidade, grupos de pressão e papel do Estado. In: Actas. Lisboa: APCP; 2001.
19. Ministério da Saúde. Decreto-Lei No 33/2012 de 13 de Fevereiro. Diário da República; 2012:3626-3633.

20. Temido $M$, Dussault $G$. Papéis profissionais de médicos e enfermeiros em Portugal: limites normativos à mudança. Rev Port Saúde Pública. 2014;2(1):45-54.

21. Assembleia da República. Proposta de Lei No 34/XIII.; 2016.

22. Entidade Reguladora da Saúde, Ordem dos Médicos, Ordem dos Enfermeiros, Ordem dos Farmacêuticos. Protocolo de Colaboração, de 18 de Novembro de 2016. Portugal; 2016. https://www.ordemdosmedicos.pt/send_ file.php?tid=ZmljaGVpcm9z\&did=4a1590df1d5968d41b855005bb8b67bf.

23. Agencia Española de Medicamentos y Productos Sanitarios, Ministerio de Sanidad y Política Social. Circular 2/2010. Espanha: CAIB; 2010.

24. INFARMED I.P. Circular Informativa 044/CD de 2010; 2010.

25. Rufai SR, Davis CR. Aesthetic surgery and Google: ubiquitous, unregulated and enticing websites for patients considering cosmetic surgery. I Plast Reconstr Aesthetic Surg. 2014;67(5):640-643. doi:10.1016/j.bjps.2014.01.009.

26. Hruza G). Clinicians Performing Cosmetic Surgery in the Community: A Nationwide Analysis of Physician Certification. Plast Reconstr Surg. 2015;136(2):274e-275e. doi:10.1097/PRS.0000000000001420.

27. Frederickson HG, Smith KB, Larimer CW, Licari MI. The Public Administration Theory Primer.; 2012. doi:10.5860/CHOICE.41-2423.

28. Waltzman JT, Scholz T, Evans GRD. What Patients Look for When Choosing a Plastic Surgeon. Ann Plast Surg. 2011;66(6):643-647. doi:10.1097/ SAP.0b013e3181e19eeb.

29. Nowak LI, Washburn JH. Patient Sources of Information and Decision Factors in Selecting Cosmetic Surgeons. Health Mark Q. 1998;15(4):45-54. doi:10.1300/J026v15n04_03.

30. Galanis C, Sanchez IS, Roostaeian I, Crisera C. Factors Influencing Patient Interest in Plastic Surgery and the Process of Selecting a Surgeon. Aesthetic Surg |. 2013;33(4):585-590. doi:10.1177/1090820X13481228.

31. Housman TS, Hancox JG, Mir MR, et al. What Specialties Perform the Most Common Outpatient Cosmetic Procedures in the United States? Dermatologic Surg. 2007;34(1):1-8. doi:10.1111/j.1524-4725.2007.34000.x.

32. Berry MG. Commentary to "Aesthetic surgery and Google: Ubiquitous, unregulated and enticing websites for patients considering cosmetic surgery." J Plast Reconstr Aesthetic Surg. 2014;67(5):644-645. doi:10.1016/j. bjps.2014.02.005.

33. Ministério da Saúde. Decreto-Lei No 238/2015 de 14 de Outubro. Portugal: Diário da República; 2015:1-26.

34. European Comittee for Standardization. CEN/TC 409: Beauty Salon Services - Requirements and Recommendations for the Provision of Service. DIN;2016.

35. Ministério da Saúde. Decreto-Lei N. 126/2014 de 22 de Agosto. Portugal: Diário da República; 2014:4400-4416.

36. Ministério da Saúde. Decreto-Lei No 46/2012, de 24 de Fevereiro.; 2012:884-890.

37. Ordem dos Médicos. Regulamento n74/2009 - Código. Portugal; 2009:1355-1369.

38. Assembleia da República. Lei No 117/2015 de 31 de Agosto. Estatuto Da Ordem Dos Médicos. Diário da República; 2015:7566-7584. 